\title{
D-amino acid oxidase activator gene $(D A O A)$ variation affects cerebrospinal fluid homovanillic acid concentrations in healthy Caucasians
}

\author{
Dimitrios Andreou • Peter Saetre • Thomas Werge • \\ Ole A. Andreassen · Ingrid Agartz • Göran C. Sedvall • \\ Håkan Hall · Lars Terenius · Erik G. Jönsson
}

Received: 13 October 2011/ Accepted: 14 March 2012/Published online: 28 March 2012

(C) The Author(s) 2012. This article is published with open access at Springerlink.com

\begin{abstract}
The D-amino acid oxidase activator (DAOA) protein regulates the function of D-amino oxidase (DAO), an enzyme that catalyzes the oxidative deamination of D-3,4-dihydroxyphenylalanine (D-DOPA) and D-serine. D-DOPA is converted to L-3,4-DOPA, a precursor of dopamine, whereas D-serine participates in glutamatergic transmission. We hypothesized that DAOA polymorphisms are associated with dopamine, serotonin and noradrenaline turnover in the human brain. Four single-nucleotide
\end{abstract}

D. Andreou $(\bowtie) \cdot$ P. Saetre $\cdot$ I. Agartz

G. C. Sedvall · H. Hall · L. Terenius · E. G. Jönsson

Department of Clinical Neuroscience, HUBIN Project,

Karolinska Institutet and Hospital, R5:00,

17176 Stockholm, Sweden

e-mail: dimitrios.andreou@sll.se

T. Werge

Research Institute of Biological Psychiatry,

Mental Health Center Sct. Hans,

Copenhagen University Hospital, Roskilde, Denmark

O. A. Andreassen

TOP Project, Division of Psychiatry, Ullevål University

Hospital, University of Oslo, Oslo, Norway

O. A. Andreassen

TOP Project, Institute of Clinical Medicine, Psychiatry Section

Vinderen, University of Oslo, Oslo, Norway

\section{Agartz}

Department of Psychiatry,

Diakonhjemmet Hospital, Oslo, Norway

I. Agartz

Institute of Psychiatry, University of Oslo, Oslo, Norway

H. Hall

Department of Public Health and Caring Sciences, Uppsala

University, Uppsala, Sweden polymorphisms, previously reported to be associated with schizophrenia, were genotyped. Cerebrospinal fluid (CSF) samples were drawn by lumbar puncture, and the concentrations of the major dopamine metabolite homovanillic acid (HVA), the major serotonin metabolite 5-hydroxyindoleacetic acid (5-HIAA) and the major noradrenaline metabolite 3-methoxy-4-hydroxyphenylglycol (MHPG) were measured. Two of the investigated polymorphisms, rs3918342 and rs1421292, were significantly associated with CSF HVA concentrations. Rs3918342 was found to be nominally associated with CSF 5-HIAA concentrations. None of the polymorphisms were significantly associated with MHPG concentrations. Our results indicate that $D A O A$ gene variation affects dopamine turnover in healthy individuals, suggesting that disturbed dopamine turnover is a possible mechanism behind the observed associations between genetic variation in $D A O A$ and behavioral phenotypes in humans.

Keywords D-amino acid oxidase activator gene (DAOA) . Cerebrospinal fluid (CSF) · Homovanillic acid (HVA) .

5-hydroxyindoleacetic acid (5-HIAA) .

3-methoxy-4-hydroxyphenylglycol (MHPG)

\section{Introduction}

The DAOA (D-amino acid oxidase activator gene) is located on chromosome $13 \mathrm{q} 34$ and spans $29 \mathrm{~Kb}$. This region, spanning $5 \mathrm{Mb}$, was initially investigated by Chumakov and colleagues, and two overlapping genes, DAOA (or $G 72$ ) and $G 30$, transcribed in opposing directions, were identified [7]. DAOA gene variation was initially associated with schizophrenia [7], and during the past decade, this association has been replicated in many subsequent studies 
(http://www.szgene.org) [2]. DAOA has also been associated with schizophrenia-related characteristics such as frontal lobe volume change [16], susceptibility to methamphetamine psychosis [26], response to antipsychotic treatment [36] and progression of prodromal syndromes to first episode psychosis [31]. Furthermore, DAOA has been associated with other psychiatric disorders and phenotypes such as major depression [40], bipolar disorder [38] and bipolar disorder severity [8]. An animal study, using $D A O A$ transgenic mice, showed behavioral phenotypes associated with psychosis, some of which could be reversed with haloperidol [34].

The DAOA protein contains 153 amino acids and has been detected in various parts of the central nervous system (CNS), including amygdala, nucleus caudatus and spinal cord [7]. DAOA has also been implicated in the regulation of mitochondrial function and dendritic branching [28]. The DAOA protein was initially reported to behave as an activator of porcine D-amino acid oxidase (DAO), whereas more recent studies showed that DAOA modulates human DAO function as a negative effector [7, 42].

DAO catalyzes the oxidative deamination of D-amino acids, such as D-3,4-dihydroxyphenylalanine (D-DOPA) and D-serine to $\alpha$-keto acids. Thus, DAO deaminates D-DOPA to its corresponding $\alpha$-keto acid, which is then transaminated to L-DOPA [24, 52]. L-DOPA then enters the basic biosynthetic pathway to dopamine and homovanillic acid (HVA). Dopamine is converted to noradrenaline by dopamine-beta-hydroxylase, and noradrenaline enters its basic catabolic pathway and is degraded to 3-methoxy4-hydroxyphenylglycol (MHPG). Kinetic data show that the maximal velocity for the oxidative deamination of D-DOPA is much higher than for D-serine [24].

D-serine is an allosteric modulator of the $N$-methyl-Daspartate (NMDA)-type glutamate receptors (NMDAR) [32], which have a modulatory site for D-serine. The occupation of this site by D-serine is required for glutamate to stimulate cation flow $[19,32]$. Interaction between glutamate and noradrenaline [9] suggests that DAOA may be associated with noradrenaline via glutamatergic mechanisms (Fig. 1).

There is also evidence of a bidirectional interaction between NMDAR and the dopamine system. NMDAR activation leads to enhanced recruitment of the dopamine D1 receptor (DRD1) to the plasma membrane [37, 44]. Moreover, there is a direct protein-protein coupling between DRD1 and NMDAR [10, 29, 37]. It has been proposed that DRD1 and NMDAR early after their biosynthesis form heteromeric complexes, which are then transported to plasma membrane as preformed units [30]. NMDA antagonists lead to an increase in midbrain dopamine neuron firing rates [11], whereas striatal dopamine release has been reported increased or decreased in some

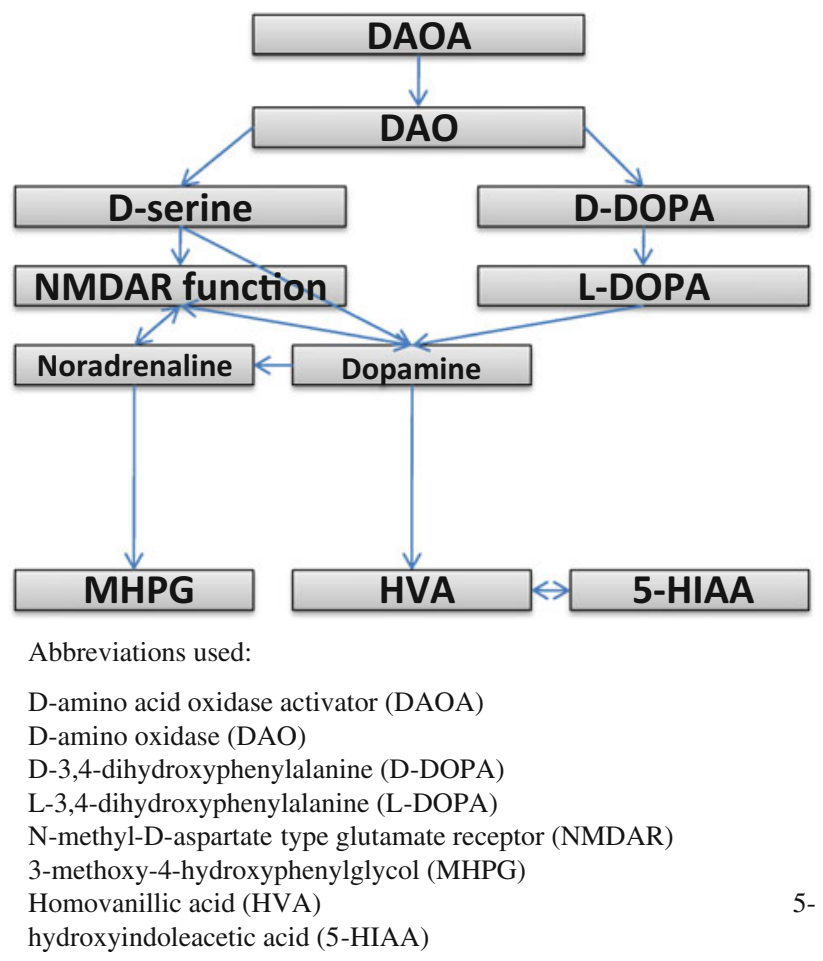

Fig. 1 Biochemical and functional connections between D-amino acid oxidase activator and cerebrospinal fluid monoamine metabolites

studies [1, 39, 49]. A direct association between D-serine and dopamine release has also been shown, as high doses of D-serine attenuated amphetamine-induced dopamine release [46].

Taken together, there are biochemical connections between DAOA and the catecholamines dopamine and noradrenaline, via two identified pathways, first via DAO, D-serine and NMDAR, and secondly via DAO and D-DOPA (Fig. 1). The concentration of the major serotonin metabolite 5-hydroxyindoleacetic acid (5-HIAA) in cerebrospinal fluid (CSF) is strongly correlated with the major dopamine metabolite HVA [13]. This suggests that DAOA may also be associated with 5-HIAA (Fig. 1).

Given these biochemical and functional connections between the DAOA protein and the monoamine metabolites and the fact that studies in human twins and other primates indicate that monoamine metabolite concentrations are partly under genetic influence [17, 18, 35, 41], we can speculate that the well-established associations between $D A O A$ and psychiatric phenotypes, described in the first paragraph, may be mediated by disturbed monoamine turnover rates.

In the present study, we aim to investigate whether $D A O A$ polymorphisms are associated with dopamine, serotonin and noradrenaline turnover in the human brain. The concentrations of the major dopamine metabolite HVA, the major serotonin metabolite 5-HIAA and the 
major noradrenaline metabolite MHPG in CSF were used as indirect indexes of the monoamine turnover.

\section{Methods}

\section{Subjects}

Unrelated healthy Caucasians, 78 men and 54 women, participated in a longitudinal study. At the first interview, when CSF was sampled, their mean ages \pm standard deviations (SD) were $27 \pm 9$ years, and all subjects were found to be healthy. Of the women, 22 used oral contraceptives at lumbar puncture, 29 did not, whereas data were missing for three female participants. Except for oral contraceptives, all subjects were drug-free at lumbar puncture. Eight to twenty years after the first investigation, all subjects were re-interviewed to re-assess the psychiatric morbidity as previously described [20, 23]. At this interview, whole blood was drawn from all participants. At the second investigation, 43 of the subjects were found to have experienced various DSM-III-R psychiatric lifetime diagnoses. The study was conducted in accordance with the Declaration of Helsinki and approved by the Ethics Committee of the Karolinska University Hospital. Informed consent was obtained from all the participating subjects.

\section{CSF monoamine metabolite concentrations}

CSF samples $(12.5 \mathrm{ml})$ were obtained by lumbar puncture and analyzed as previously described [22, 45, 47]. Briefly, the samples were drawn between 8 and 9 a.m. with the subjects in the sitting or recumbent position, after at least $8 \mathrm{~h}$ of bed rest and absence of food intake or smoking. 5-HIAA, HVA and MHPG concentrations were measured by mass fragmentography with deuterium-labeled standards. Back-length was defined as the distance between the external occipital protuberance and the point of needle insertion.

\section{DNA analysis}

Genomic DNA was extracted from whole blood [12]. Four DAOA SNPs (rs2391191 or M15, rs778294 or M19, rs3918342 or M23, rs1421292 or M24), previously reported to be associated with schizophrenia, were selected and genotyped at the SNP Technology Platform at Uppsala University and Uppsala University Hospital, Sweden (http://www.genotyping.se), using the Illumina BeadStation 500GX and the 1536-plex Illumina Golden Gate assay (Illumina Inc., San Diego, CA, USA) as previously described [21].
Statistical analysis

Hardy-Weinberg (HW) equilibrium was tested using Fisher's exact test as implemented in PEDSTATS [51]. Linkage disequilibrium ( $\mathrm{D}^{\prime}$ and $r^{2}$ ) between SNP pairs was determined with Haploview 4.0 [3]. Allele association between DAOA SNPs and CSF monoamine metabolite concentrations was tested with a general linear model (Proc GLM, SAS/STAT ${ }^{\circledR}$ software, version 9.1.3, SAS institute Inc., Cary, NC, USA), where concentration was modeled as a linear function of the allele count (of each SNP separately) and one or more covariates (single-marker association).

Covariates were selected by preliminary analysis excluding genetic markers. That is, the effect of potentially important confounders (back-length, weight, gender, age at lumbar puncture and presence of a lifetime psychiatric diagnosis) on CSF monoamine metabolite concentrations was evaluated by forward stepwise selection, as previously described [20]. Confounders that explained a significant part of systematic variation in CSF concentrations $(P<0.1)$ were included as covariates in the genetic association analysis. Thus, back-length and presence of a lifetime psychiatric diagnosis were used as covariates in the analysis of 5-HIAA and HVA concentrations, whereas back-length and gender were included in the analyses of MHPG. We tested the normal distribution of residuals with the Anderson-Darling test, and residuals were approximately normally distributed after square root (5-HIAA, HVA) and logarithmic (MHPG) transformations. Correction for multiple testing was performed through random permutation of the four marker genotypes among individuals and recalculation of the $P$ values for the 12 tests for each permuted data set (1,000 permuted data sets). The corrected $P$ value was then calculated as the fraction of permutated data sets where the minimum $P$ value from the 12 tests was equal to, or smaller than, the observed $P$ value. Moreover, rs3918342, showing the strongest association with HVA, was selected for further analysis, applying a dominant model of segregation.

\section{Results}

The mean (SD) concentrations of the three monoamine metabolites were: HVA, 170.2 (72.3) nmol/L; 5-HIAA, 91.7 (37.4) nmol/L; MHPG, 41.6 (8.2) nmol/L. Two of the investigated polymorphisms, rs3918342 (Fig. 2) and rs1421292, were found to be significantly associated with CSF HVA concentrations with corrected $P$ values 0.013 and 0.043 , respectively (Table 1). Rs3918342 was nominally associated with CSF 5-HIAA concentration, but this association was not statistically significant when 


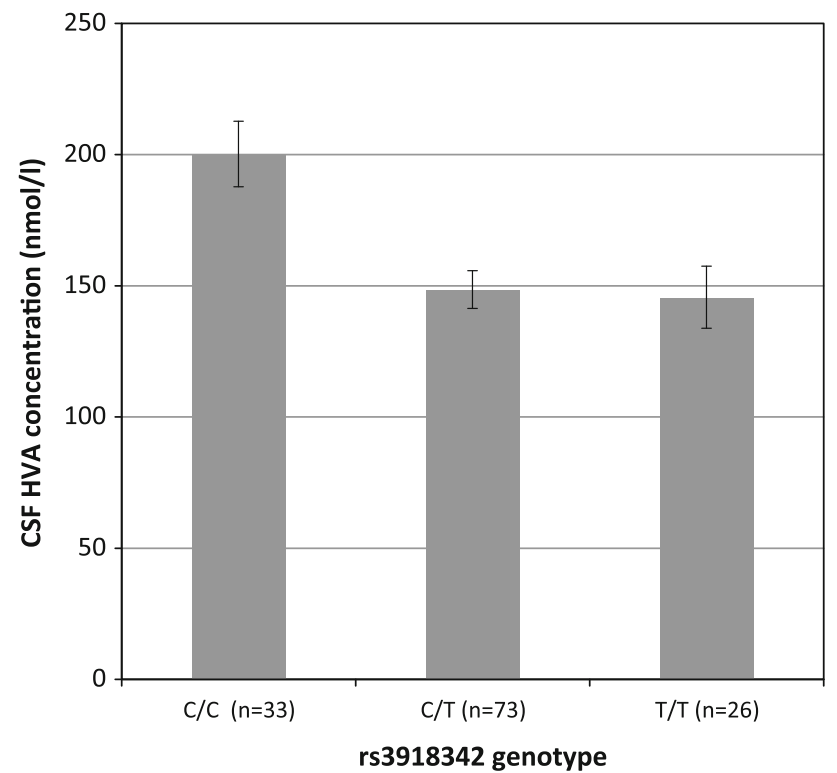

Fig. 2 Cerebrospinal fluid (CSF) homovanillic acid (HVA) concentration in healthy subjects as a function of the number of rs3918342 T-alleles (corrected $P$ value $=0.013$ ). Least square means and standard errors are given

accounting for the number of tests conducted. No polymorphisms were associated with MHPG concentrations.

The two SNPs associated with HVA concentrations, rs3918342 and rs1421292, are in strong linkage disequilibrium (LD; $r^{2}=0.80$ ) in Caucasians (HapMap, release 24). In the Scandinavian population, the two markers are in almost complete LD $\left(r^{2}=0.99\right)$ [21], and thus, they captured the same association signal in this study. Consequently, rs1421292 explained no additional variation in HVA concentration $(P=0.95)$ on top of that explained by rs3918342.

Carriers of the rs $3918342 \mathrm{~T}$ allele (both $\mathrm{C} / \mathrm{T}$ and $\mathrm{T} / \mathrm{T}$ ) had $50 \mathrm{nmol} / \mathrm{l}$ lower HVA mean concentrations compared with $\mathrm{C}$ homozygotes; no difference in HVA mean concentrations was found between $\mathrm{C} / \mathrm{T}$ and $\mathrm{T} / \mathrm{T}$ (Fig. 2). This pattern is consistent with a dominant model of segregation ( $\mathrm{T}$ allele dominant), and as expected, this model resulted in a substantial decrease in the uncorrected $P$ value for the association between rs3918342 and HVA (from 0.0016 to 0.0001 ).

\section{Discussion}

In the present study, two DAOA polymorphisms, rs3918342 and rs1421292, were significantly associated with CSF HVA concentrations. Rs3918342 and rs1421292 are located 42 and $55 \mathrm{kbp}$ from the $3^{\prime}$ end of DAOA, respectively, and are in strong linkage disequilibrium. Rs3918342 and rs1421292 have not been ascribed any functionality and were not found to be associated in strong
LD $\left(r^{2}>0.6\right)$ with any SNP within the DAOA borders. However, both were in strong LD with some intergenic SNPs within $500 \mathrm{kbp}$ from rs3918342 (HapMap release 24). The associated intergenic SNPs lack currently known function or association with mental disorders.

During the past decades, a large number of CSF candidate markers, including the monoamine metabolite HVA, have been investigated with regard to their relevance to schizophrenia [48]. HVA concentrations have been reported to be significantly lower in drug-free schizophrenic patients compared with controls $[6,50]$. Both quetiapine and olanzapine administrations have been associated with a significant increase in CSF HVA [33, 43], whereas haloperidol withdrawal resulted in a significant decrease in CSF HVA [5]. Thus, decreased HVA concentration appears to be related to schizophrenia.

There are several studies suggesting that a locus located near the $3^{\prime}$ end of $D A O A$ is associated with phenotypes characteristic of schizophrenia or the progression of the disease. For example, both rs3918342 and rs1421292 have been associated with attention and memory impairments in schizophrenic individuals [14]. Rs3918342 has been associated with decreased hippocampal activation and increased prefrontal activation in subjects at high genetic risk of schizophrenia [15], as well as temporal lobe and amygdala gray matter reduction [53]. Furthermore, rs1421292 has been associated with brain activation in the right middle temporal gyrus and the right precuneus in healthy individuals [27]. Rs3918342 has been significantly associated with schizophrenia in independent studies [4, 7, 25]. However, meta-analysis of rs 3918342 suggests that the association is restricted to populations of Caucasian origin and that the effect size is small (odds ratio $=1.03$, nonsignificant; http://www.szgene.org) [2].

We found the TT genotype of rs3918342 to be strongly associated with decreased HVA concentrations, and we note that it is also this genotype that has been associated with attention and memory impairments in schizophrenic individuals [14], decreased hippocampal activation and increased prefrontal activation in subjects at high genetic risk of schizophrenia [15] as well as temporal lobe and amygdala gray matter reduction in bipolar patients [53]. Thus, it is possible that a disturbed dopamine turnover, reflected by decreased HVA levels, may be a mechanism behind one or several of the cognitive, neurological and brain morphological phenotypes previously associated with the rs3918342 TT genotype.

In conclusion, our results suggest that $D A O A$ gene variation significantly affects dopamine turnover in CNS of healthy controls. Further research is needed in order to replicate our findings in healthy controls and, moreover, to find out whether the present associations can also be observed in schizophrenia and other psychiatric disorders. 


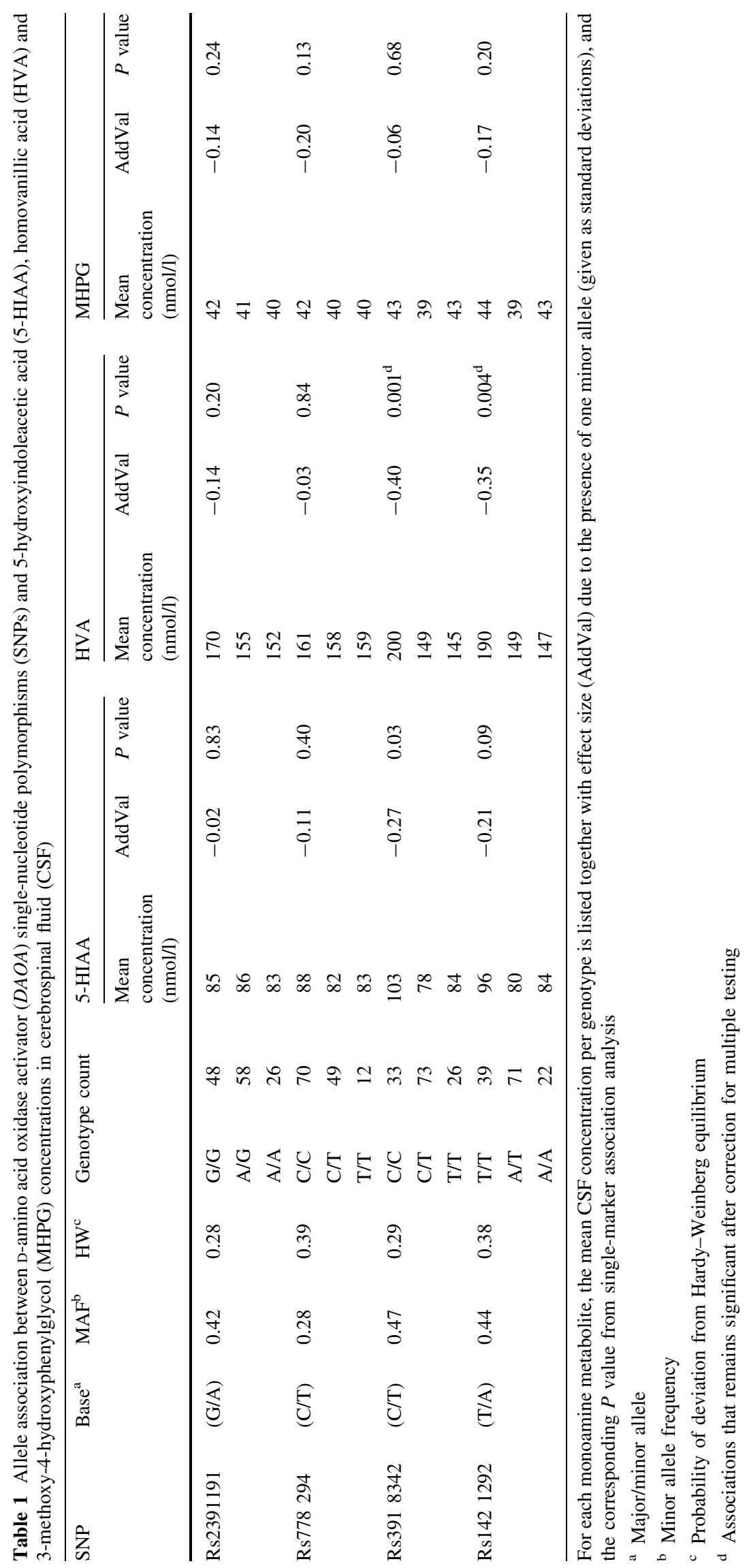


Acknowledgments This study was financed by the Swedish Research Council (2006-2992, 2006-986, and 2008-2167), the regional agreement on medical training and clinical research between Stockholm County Council and the Karolinska Institutet, the Knut and Alice Wallenberg Foundation and the HUBIN project. TW was financed by the Copenhagen Hospital Corporation Research Fund, the Danish National Psychiatric Research Foundation, the Danish Agency for Science, and Technology and Innovation (Centre for Pharmacogenetics). OAA was financed by the Research Council of Norway (147787 and 167153), the Eastern Norway Health Authority (Helse Øst RHF 123/2004), Ullevål University Hospital, and University of Oslo. We thank Alexandra Tylec, Agneta Gunnar, Monica Hellberg and Kjerstin Lind for technical assistance. We also thank Kristina Larsson, Tomas Axelsson and Ann-Christine Syvänen at the SNP Technology Platform in Uppsala for performing the genotyping. The SNP Technology Platform is supported by Uppsala University, Uppsala University Hospital and by the Knut and Alice Wallenberg Foundation.

\section{Conflict of interest None.}

Open Access This article is distributed under the terms of the Creative Commons Attribution License which permits any use, distribution, and reproduction in any medium, provided the original author(s) and the source are credited.

\section{References}

1. Adams BW, Bradberry CW, Moghaddam B (2002) NMDA antagonist effects on striatal dopamine release: microdialysis studies in awake monkeys. Synapse 43:12-18

2. Allen NC, Bagade S, McQueen MB, Ioannidis JPA, Kavvoura FK, Khoury MJ, Tanzi RE, Bertram L (2008) Systematic metaanalyses and field synopsis of genetic association studies in schizophrenia: the SzGene database. Nat Genet 40:827-834

3. Barrett JC, Fry B, Maller J, Daly MJ (2005) Haploview: analysis and visualization of LD and haplotype maps. Bioinformatics 21:263-265

4. Bass NJ, Datta SR, McQuillin A, Puri V, Choudhury K, Thirumalai S, Lawrence J, Quested D, Pimm J, Curtis D, Gurling HM (2009) Evidence for the association of the DAOA (G72) gene with schizophrenia and bipolar disorder but not for the association of the DAO gene with schizophrenia. Behav Brain Funct 5:28

5. Beuger M, van Kammen DP, Kelley ME, Yao J (1996) Dopamine turnover in schizophrenia before and after haloperidol withdrawal. Neuropsychopharmacology 15:75-86

6. Bjerkenstedt L, Edman G, Hagenfeldt L, Sedvall G, Wiesel F-A (1985) Plasma amino acids in relation to cerebrospinal fluid monoamine metabolites in schizophrenic patients and healthy controls. Br J Psychiatry 147:276-282

7. Chumakov I, Blumenfeld M, Guerassimenko O, Cavarec L, Palicio M, Abderrahim H, Bougueleret L, Barry C, Tanaka H, La Rosa P, Puech A, Tahri N, Cohen-Akenine A, Delabrosse S, Lissarrague S, Picard FP, K M, Essioux L, Millasseau P, Grel P, Debailleul V, Simon AM, Caterina D, Dufaure I, Malekzadeh K, Belova M, Luan JJ, Bouillot M, Sambucy JL, Primas G, Saumier M, Boubkiri N, Martin-Saumier S, Nasroune M, Peixoto H, Delaye A, Pinchot V, Bastucci M, Guillou S, Chevillon M, SainzFuertes R, Meguenni S, Aurich-Costa J, Cherif D, Gimalac A, Van Duijn C, Gauvreau D, Ouellette G, Fortier I, Raelson J, Sherbatich T, Riazanskaia N, Rogaev E, Raeymaekers P,
Aerssens J, Konings F, Luyten W, Macciardi F, Sham PC, Straub RE, Weinberger DR, Cohen N, Cohen D (2002) Genetic and physiological data implicating the new human gene G72 and the gene for D-amino acid oxidase in schizophrenia. Proc Natl Acad Sci USA 99:13675-13680

8. Dalvie S, Horn N, Nossek C, van der Merwe L, Stein DJ, Ramesar R (2010) Psychosis and relapse in bipolar disorder are related to GRM3, DAOA, and GRIN2B genotype. Afr J Psychiatry (Johannesbg) 13:297-301

9. Feldman S, Weidenfeld J (2004) Involvement of endogeneous glutamate in the stimulatory effect of norepinephrine and serotonin on the hypothalamo-pituitary-adrenocortical axis. Neuroendocrinology 79:43-53

10. Fiorentini C, Gardoni F, Spano P, Di Luca M, Missale C (2003) Regulation of dopamine D1 receptor trafficking and desensitization by oligomerization with glutamate N-methyl-D-aspartate receptors. J Biol Chem 278:20196-20202

11. French ED (1994) Phencyclidine and the midbrain dopamine system: electrophysiology and behavior. Neurotoxicol Teratol $16: 355-362$

12. Geijer T, Neiman J, Rydberg U, Gyllander A, Jönsson E, Sedvall G, Valverius P, Terenius L (1994) Dopamine D2 receptor gene polymorphisms in Scandinavian chronic alcoholics. Eur Arch Psychiatry Clin Neurosci 244:26-32

13. Geracioti TD Jr, Keck PE Jr, Ekhator NN, West SA, Baker DG, Hill KK, Bruce AB, Wortman MD (1998) Continuous covariability of dopamine and serotonin metabolites in human cerebrospinal fluid. Biol Psychiatry 44:228-233

14. Goldberg TE, Straub RE, Callicott JH, Hariri A, Mattay VS, Bigelow L, Coppola R, Egan MF, Weinberger DR (2006) The G72/G30 gene complex and cognitive abnormalities in schizophrenia. Neuropsychopharmacology 31:2022-2032

15. Hall J, Whalley HC, Moorhead TW, Baig BJ, McIntosh AM, Job DE, Owens DG, Lawrie SM, Johnstone EC (2008) Genetic variation in the DAOA (G72) gene modulates hippocampal function in subjects at high risk of schizophrenia. Biol Psychiatry 64:428-433

16. Hartz SM, Ho BC, Andreasen NC, Librant A, Rudd D, Epping EA, Wassink TH (2010) G72 influences longitudinal change in frontal lobe volume in schizophrenia. Am J Med Genet B Neuropsychiatr Genet 153B:640-647

17. Higley JD, Mehlman PT, Higley SB, Fernald B, Vickers J, Lindell SG, Taub DM, Suomi SJ, Linnoila M (1996) Excessive mortality in young free-ranging male nonhuman primates with low cerebrospinal fluid 5-hydroxyindoleacetic acid concentrations. Arch Gen Psychiatry 53:537-543

18. Higley JD, Thompson WW, Champoux M, Goldman D, Hasert MF, Kraemer GW, Scanlan JM, Suomi SJ, Linnoila M (1993) Paternal and maternal genetic and environmental contributions to cerebrospinal fluid monoamine metabolites in rhesus monkeys (Macaca mulatta). Arch Gen Psychiatry 50:615-623

19. Johnson JW, Ascher P (1987) Glycine potentiates the NMDA response in cultured mouse brain neurons. Nature 325:529-531

20. Jonsson EG, Saetre P, Edman-Ahlbom B, Sillen A, Gunnar A, Andreou D, Agartz I, Sedvall G, Hall H, Terenius L (2008) Brainderived neurotrophic factor gene variation influences cerebrospinal fluid 3-methoxy-4-hydroxyphenylglycol concentrations in healthy volunteers. J Neural Transm 115:1695-1699

21. Jonsson EG, Saetre P, Vares M, Andreou D, Larsson K, Timm S, Rasmussen HB, Djurovic S, Melle I, Andreassen OA, Agartz I, Werge T, Hall H, Terenius L (2009) DTNBP1, NRG1, DAOA, DAO and GRM3 polymorphisms and schizophrenia: an association study. Neuropsychobiology 59:142-150 
22. Jönsson E, Sedvall G, Brené S, Gustavsson JP, Geijer T, Terenius L, Crocq M-A, Lannfelt L, Tylec A, Sokoloff P, Schwartz JC, Wiesel F-A (1996) Dopamine-related genes and their relationships to monoamine metabolites in CSF. Biol Psychiatry 40:1032-1043

23. Jönsson EG, Bah J, Melke J, Abou Jamra R, Schumacher J, Westberg L, Ivo R, Cichon S, Propping P, Nöthen MM, Eriksson E, Sedvall GC (2004) Monoamine related functional gene variants and relationships to monoamine metabolite concentrations in CSF of healthy volunteers. BMC Psychiatry $4: 4$

24. Kawazoe T, Park HK, Iwana S, Tsuge H, Fukui K (2007) Human D-amino acid oxidase: an update and review. Chem Rec 7:305-315

25. Korostishevsky M, Kaganovich M, Cholostoy A, Ashkenazi M, Ratner Y, Dahary D, Bernstein J, Bening-Abu-Shach U, BenAsher E, Lancet D, Ritsner M, Navon R (2004) Is the G72/G30 locus associated with schizophrenia? Single nucleotide polymorphisms, haplotypes, and gene expression analysis. Biol Psychiatry $56: 169-176$

26. Kotaka T, Ujike H, Okahisa Y, Takaki M, Nakata K, Kodama M, Inada T, Yamada M, Uchimura N, Iwata N, Sora I, Iyo M, Ozaki N, Kuroda S (2009) G72 gene is associated with susceptibility to methamphetamine psychosis. Prog Neuropsychopharmacol Biol Psychiatry 33:1046-1049

27. Krug A, Markov V, Krach S, Jansen A, Zerres K, Eggermann T, Stocker T, Shah NJ, Nothen MM, Georgi A, Strohmaier J, Rietschel M, Kircher T (2011) Genetic variation in G72 correlates with brain activation in the right middle temporal gyrus in a verbal fluency task in healthy individuals. Hum Brain Mapp $32: 118-126$

28. Kvajo M, Dhilla A, Swor DE, Karayiorgou M, Gogos JA (2008) Evidence implicating the candidate schizophrenia/bipolar disorder susceptibility gene G72 in mitochondrial function. Mol Psychiatry 13:685-696

29. Lee FJ, Xue S, Pei L, Vukusic B, Chery N, Wang Y, Wang YT, Niznik HB, Yu XM, Liu F (2002) Dual regulation of NMDA receptor functions by direct protein-protein interactions with the dopamine D1 receptor. Cell 111:219-230

30. Missale C, Fiorentini C, Busi C, Collo G, Spano PF (2006) The NMDA/D1 receptor complex as a new target in drug development. Curr Top Med Chem 6:801-808

31. Mossner R, Schuhmacher A, Wagner M, Quednow BB, Frommann I, Kuhn KU, Schwab SG, Rietschel M, Falkai P, Wolwer W, Ruhrmann S, Bechdolf A, Gaebel W, Klosterkotter J, Maier W (2010) DAOA/G72 predicts the progression of prodromal syndromes to first episode psychosis. Eur Arch Psychiatry Clin Neurosci 260:209-215

32. Mothet JP, Parent AT, Wolosker H, Brady RO Jr, Linden DJ, Ferris CD, Rogawski MA, Snyder SH (2000) D-serine is an endogenous ligand for the glycine site of the N-methyl-D-aspartate receptor. Proc Natl Acad Sci USA 97:4926-4931

33. Nikisch G, Baumann P, Wiedemann G, Kiessling B, Weisser H, Hertel A, Yoshitake T, Kehr J, Mathe AA (2010) Quetiapine and norquetiapine in plasma and cerebrospinal fluid of schizophrenic patients treated with quetiapine: correlations to clinical outcome and HVA, 5-HIAA, and MHPG in CSF. J Clin Psychopharmacol 30:496-503

34. Otte DM, Bilkei-Gorzo A, Filiou MD, Turck CW, Yilmaz O, Holst MI, Schilling K, Abou-Jamra R, Schumacher J, Benzel I, Kunz WS, Beck H, Zimmer A (2009) Behavioral changes in G72/ G30 transgenic mice. Eur Neuropsychopharmacol 19:339-348

35. Oxenstierna G, Edman G, Iselius L, Oreland L, Ross SB, Sedvall G (1986) Concentrations of monoamine metabolites in the cerebrospinal fluid of twins and unrelated individuals - a genetic study. J Psychiatr Res 20:19-29
36. Pae CU, Chiesa A, Serretti A (2010) Influence of DAOA gene variants on antipsychotic response after switch to aripiprazole. Psychiatry Res 178:430-432

37. Pei L, Lee FJ, Moszczynska A, Vukusic B, Liu F (2004) Regulation of dopamine D1 receptor function by physical interaction with the NMDA receptors. J Neurosci 24:1149-1158

38. Prata D, Breen G, Osborne S, Munro J, St Clair D, Collier D (2008) Association of DAO and G72(DAOA)/G30 genes with bipolar affective disorder. Am J Med Genet B Neuropsychiatr Genet 147B:914-917

39. Rao TS, Kim HS, Lehmann J, Martin LL, Wood PL (1989) Differential effects of phencyclidine (PCP) and ketamine on mesocortical and mesostriatal dopamine release in vivo. Life Sci 45:1065-1072

40. Rietschel M, Beckmann L, Strohmaier J, Georgi A, Karpushova A, Schirmbeck F, Boesshenz KV, Schmal C, Burger C, Jamra RA, Schumacher J, Hofels S, Kumsta R, Entringer S, Krug A, Markov V, Maier W, Propping P, Wust S, Kircher T, Nothen MM, Cichon S, Schulze TG (2008) G72 and its association with major depression and neuroticism in large population-based groups from Germany. Am J Psychiatry 165:753-762

41. Rogers J, Martin LJ, Comuzzie AG, Mann JJ, Manuck SB, Leland M, Kaplan JR (2004) Genetics of monoamine metabolites in baboons: overlapping sets of genes influence levels of 5-hydroxyindolacetic acid, 3-hydroxy-4-methoxyphenylglycol, and homovanillic acid. Biol Psychiatry 55:739-744

42. Sacchi S, Bernasconi M, Martineau M, Mothet JP, Ruzzene M, Pilone MS, Pollegioni L, Molla G (2008) pLG72 modulates intracellular D-serine levels through its interaction with D-amino acid oxidase: effect on schizophrenia susceptibility. J Biol Chem 283:22244-22256

43. Scheepers FE, Gispen-de Wied CC, Westenberg HG, Kahn RS (2001) The effect of olanzapine treatment on monoamine metabolite concentrations in the cerebrospinal fluid of schizophrenic patients. Neuropsychopharmacology 25:468-475

44. Scott L, Kruse MS, Forssberg H, Brismar H, Greengard P, Aperia A (2002) Selective up-regulation of dopamine D1 receptors in dendritic spines by NMDA receptor activation. Proc Natl Acad Sci USA 99:1661-1664

45. Sedvall GC, Wode-Helgodt B (1980) Aberrant monoamine metabolite levels in CSF and family history of schizophrenia. Their relationships in schizophrenic patients. Arch Gen Psychiatry 37:1113-1116

46. Smith SM, Uslaner JM, Yao L, Mullins CM, Surles NO, Huszar SL, McNaughton CH, Pascarella DM, Kandebo M, Hinchliffe RM, Sparey T, Brandon NJ, Jones B, Venkatraman S, Young MB, Sachs N, Jacobson MA, Hutson PH (2009) The behavioral and neurochemical effects of a novel D-amino acid oxidase inhibitor compound 8 [4H-thieno [3,2-b]pyrrole-5-carboxylic acid] and D-serine. J Pharmacol Exp Ther 328:921-930

47. Swahn C-G, Sandgärde B, Wiesel F-A, Sedvall G (1976) Simultaneous determination of the three major monoamine metabolites in brain tissue and body fluids by a mass fragmentographic method. Psychopharmacology 48:147-152

48. Vasic N, Connemann BJ, Wolf RC, Tumani H, Brettschneider J (2011) Cerebrospinal fluid biomarker candidates of schizophrenia: where do we stand? Eur Arch Psychiatry Clin Neurosci. doi: 10.1007/s00406-00011-00280-00409

49. Wheeler D, Boutelle MG, Fillenz M (1995) The role of $\mathrm{N}$-methyl-D-aspartate receptors in the regulation of physiologically released dopamine. Neuroscience 65:767-774

50. Wieselgren I-M, Lindström LH (1998) CSF levels of HVA and 5-HIAA in drug-free schizophrenic patients and healthy controls: a prospective study focused on their predictive value for outcome in schizophrenia. Psychiatry Res 81:101-110 
51. Wigginton JE, Abecasis GR (2005) PEDSTATS: descriptive statistics, graphics and quality assessment for gene mapping data. Bioinformatics 21:3445-3447

52. Wu M, Zhou XJ, Konno R, Wang YX (2006) D-dopa is unidirectionally converted to L-dopa by D-amino acid oxidase, followed by dopa transaminase. Clin Exp Pharmacol Physiol 33:1042-1046
53. Zuliani R, Moorhead TW, Job D, McKirdy J, Sussmann JE, Johnstone EC, Lawrie SM, Brambilla P, Hall J, McIntosh AM (2009) Genetic variation in the G72 (DAOA) gene affects temporal lobe and amygdala structure in subjects affected by bipolar disorder. Bipolar Disord 11:621-627 